\title{
"Hubungan Penggunaan ATS (Australasian Triage Scale) Modifikasi Terhadap Response Time Perawat di Instalasi Gawat Darurat”
}

\begin{abstract}
ABSTRAK
Pendahuluan: Triase merupakan proses memilah pasien menurut tingkat keparahannnya. Proses triase berperan penting dalam mengatasi alur masuk pasien di unit gawat darurat sehingga pasien tertangani sesuai kegawatannya dan tidak terjadi penumpukan dalam ruang gawat darurat. Namun fenomena yang terjadi dibeberapa rumah sakit, peaksanaan triase ATS masih belum sesuai dengan standar waktu yang ditetapkan dalam sistem Australasian Triage Scale. Tujuan dari penelitian ini untuk melihat hubungan antara penggunaan standar operasional prosedur penerimaan pasien baru dengan memakai sistem triase ATS (Australasian Triage Scale) yang dimodifikasi dengan kecepatan response time perawat instalasi gawat darurat. Metode: Penelitian ini menggunakan desain analitik korelatif dengan pendekatan study kasus. Total populasi sebesar 31 orang dan didapatkan sampel 28 orang melalui kriteria inklusi dan esklusi. Variabel independen dalam penelitian ini adalah Penggunaan ATS (Australasian Triage Scale) serta variabel dependen dalam penelitian ini adalah Response Time perawat. Data didapatkan dengan cara observasi sampel dan dianalisis dengan menggunakan uji korelasi spearman rho. Hasil: Tidak terdapat hubungan antara penggunaan ATS (Australasian Triage Scale) modifikasi dengan response time perawat baik di dinas pagi $(p=0,720)$, dinas siang $(p=0,866)$ maupun dinas malam $(p=0,173)$ Penggunaan ATS (Australasian Triage Scale) modifikasi dan response time perawat yang sesuai dan cepat ditemukan pada dinas pagi. Diskusi: Dapat disimpulkan, hal ini disebabkan oleh beberapa faktor baik dari perawat sendiri maupun dari pihak Rumah sakit. Sebagian besar perawat tidak mendapatkan pelatihan mengenai triase dan hal ini mempengaruhi skill perawat dalam melakukan pemilahan pasien. Peneliti selanjutnya dapat menggali faktor-faktor yang memengaruhi response time perawat (selain faktor penggunaan ATS) dan dapat mengembangkan instrumen penelitian lembaran observasi dengan mengambil rujukan dari teori-teori yang ada.
\end{abstract}

Kata Kunci: ATS (Australasian Triage Scale), Response Time, Perawat Gawat Darurat 


\title{
ABSTRACT \\ Correlations to the Use of ATS (Australasian Triage Scale) Modification with Nurse Response Time in the Emergency Installation
}

\author{
Analitik korelatif study in emergency unit

\section{By: Sofiyanti Normalinda Banoet}

Introduction: Triage is the process of sorting patients according to their severity. However, the phenomena that occur in the emergency room some hospitals are different, triage is not carried out according to the standars. This is due to many factors, one of which is the triage model used. The purpose of this study was to look at the relationship between the use of Standart Operational Procedure for admitting new patients using Australasian Triage Scale which was modified with the speed of response time of nursis in the emergency installation. Method: This study used correlative analytic design with a case study approach. The total population is 31 people and a sample of 28 people was obtained through inclusion and exclusion criteria. The independent variable in this study was the use of ATS (Australasian Triage Scale) and the dependent variable in this study is the nurse's Response Time. Data obtained by means of sample observation and analyzed using the Spearman correlation test rho. Results: There was no relationship between the use of ATS (Australasian Triage Scale) modification and the response time of nurses in morning service $(p=0.720)$, afternoon service $(p=$ 0.866 ) and night service ( $p=0.173$ ) Use of ATS (Australasian Triage Scale) The appropriate and fast modification and response time of nurses was found at morning service. Discussion: It can be concluded, this is caused by several factors both from the nurses themselves and from the hospital side. Most nurses do not get training in triage and this affects nurses' skills in sorting patients. The next researcher can explore the factors that influence the nurse's response time (other than the use of ATS factors) and can develop an observation sheet research instrument by taking references from existing theories.

Keywords: ATS (Australasian Triage Scale), Response Time, Emergency Nurse 